\title{
Pest Damage Incidence in Natural and Thinned Lodgepole Pine in Alberta
}

by

I.E. Bella ${ }^{1}$

\begin{abstract}
Thinned stands of young lodgepole pine (Pinus contorta Dougl. var. latifolia Engelm.) in west-central Alberta had a higher incidence of attack by common pest organisms than unthinned stands. Based on a sample of nearly 3000 potential crop trees (on 240 temporary plots) growing on 120 naturally regenerated cut blocks, the rate of attack in thinned vs. unthinned stands was $30 \%$ and $18 \%$ for western gall rust (Endocronartium harknessii (J.P. Moore) Y. Hiratsuka) and $25 \%$ and $16 \%$ for leader damage due to terminal weevil (Pissodes terminalis Hopp.) and pitch twig moth (Petrova spp.) Damage from other agents, including that from small mammals, was low and little affected by thinning.
\end{abstract}

Forest management implication of these results are discussed.

Key words: western gall rust, terminal weevil, pitch twig moth, snowshoe hares, red squirrels.

\section{Résumé}

L'incidence des attaques par des organismes courants est plus élevée dans des peuplements éclaircis de jeunes pins tordus (Pinus contorta var. latifolia Engelm.) du centre-ouest de l'Alberta que dans des peuplements non éclaircis. Dans un échantillon de près de 3000 arbres potentiels de récolte (sur 240 parcelles temporaires) poussant dans 120 blocs de coupe régénérés naturellement, l'incidence de la rouille-tumeur de l'Ouest (Endrocronartium harknessii (J.P. Moore) Y. Hiratsuka) dans les peuplements éclaircis et non éclaircis est respectivement de 30 et $18 \%$ et l'incidence des dommages à la pousse apicale dus aux charancons (Pissodes terminalis Hopp.) et aux noduliers (Petrova spp.), de 25 et $16 \%$. Les dommages attribuables à d'autres agents, y compris ceux des petits mammifères, sont relativement faibles et peu modifiés par l'éclaircie.

L'importance de ces résultats pour la gestion des forêts est examinée.

Mots clés: rouille-tumeur, charancons, noduliers, lièvres d'Amérique, écureuils roux.

\section{Introduction}

Precommercial thinning, also referred to as spacing, is increasing in importance as a silvicultural technique to improve the growth and merchantable yield of dense lodgepole pine (Pinus contorta Dougl var. latifolia Engelm.) stands. Recent observations in spacing trials conducted by the Canadian Forestry Service (CFS) in lodgepole pine stands $50 \mathrm{~km}$ south of Hinton, Alberta, revealed localized high incidences of damage from insects, diseases, and small mammals, especially on good sites in the most open treatments of 500 and 1000 trees per ha (also see Johnstone 1981, 1983).

1Research Scientist, Northern Forest Research Centre, Canadian Forestry Service, Agriculture Canada, 5320-122 Street, Edmonton, Alta. T6H 355
Increased utilization and intensification of management of the lodgepole pine cover type in western North America has drawn attention to similar problems. Small mammals can have a particularly dramatic impact on young stands (Sullivan and Sullivan 1982).

Serious loss in timber production may occur, particularly at wide spacings, if damage is extensive and leads to reduced growth or death of trees. Consequently, there is some concern among forest managers in the region about the effectiveness and wisdom of thinning such stands. This paper addresses such concerns by providing factual information on the incidence of damage by some of the more important pests in thinned and unthinned young stands of lodgepole pine that regenerated naturally after logging to determine whether 
operational thinning by individual tree selection results in real increases in pest damage incidence. The paper also briefly discusses the possible implications of damage incidence on future yield.

\section{Methods and Description of the Area}

Sampling was done in the Edson Forest on the lease area of St. Regis (Alberta) Ltd. near Hinton (Fig. 1). The sampled stands were located within the Lower and the Upper Foothills Sections (B.19a and B.19c) of the Boreal Forest Region (Rowe 1972) and were predominantly lodgepole pine between 15 and 25 years of age (Fig. 2). These stands also have an admixture of white and black spruce (Picea glauca (Moench) Voss and $P$. mariana (Mill.) B.S.P.) and a scattering of balsam and alpine fir (Abies balsamea (L). Mill and A. lasiocarpa (Hook.) Nutt.) and tamarack (Larix laricina (Du Roi) K. Koch). Aspen (Populus tremuloides Michx.), balsam poplar ( $P$. balsamifera L.), and white birch (Betula papyrifera Marsh.) are common in the Lower Foothills Section, especially in young stands, and are relatively sparse in the Upper Foothills Section.

St. Regis (Alberta) Ltd. initiated a program of spacing young stands on former cut blocks along logging roads in its lease area in 1972, and continued between 1977 and 1981, leaving less-accessible stands untreated. This provided a good opportunity to sample thinned and unthinned stands in close proximity. Working circles (W.C.), as designated by the company and shown in Fig. 1, represent distinct geographic units as well as areas with somewhat similar growing conditions. Working circles are divided into compartments, which are subdivided into cut blocks with an average size of about 30 ha. Within the 57 thinned and 64 unthinned blocks selected for sampling, two plots were established (total 242) - one approximately $20 \mathrm{~m}$ from the stand edge, the other $30 \mathrm{~m}$ away. If a plot fell in an opening, it was moved further along the same transect to a stocked area. Circular plots of $30 \mathrm{~m}^{2}$ and $20 \mathrm{~m}^{2}$ were used in the thinned block and the unthinned block respectively, so that the number of trees tallied would be similar. Some descriptive stand statistics are summarized in Table 1.

On each plot, the $\mathrm{dbh}$ (diameter at breast height) of every tree by species and the heights of the four largest trees were measured. Also, the condition of each tree that reached breast height was tallied using the following categories:

0 - healthy and without damage,

1 - browsed top and/or branches,

2 - stem chewed - light,

3 - stem chewed - moderate to severe,

4 - stem, or branches or both infested by western gall rust (Endocronartium harknessii (J.P. Moore) Y. Hiratsuka),

5 - needle cast infection (Lophodermella spp.),

6 - chlorotic condition,

7 - leader damage due to lodgepole terminal weevil (Pissodes terminalis Hopp.), and/or pitch twig moth (Petrova spp.),

8 - damage other than categories 1 to 7

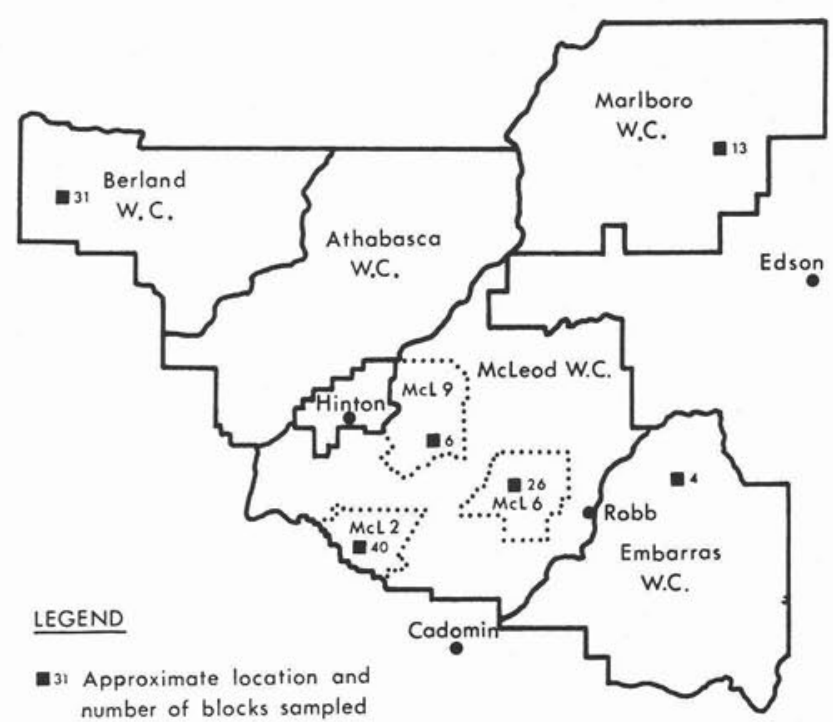

Figure 1. Location of sampling areas by working circles.

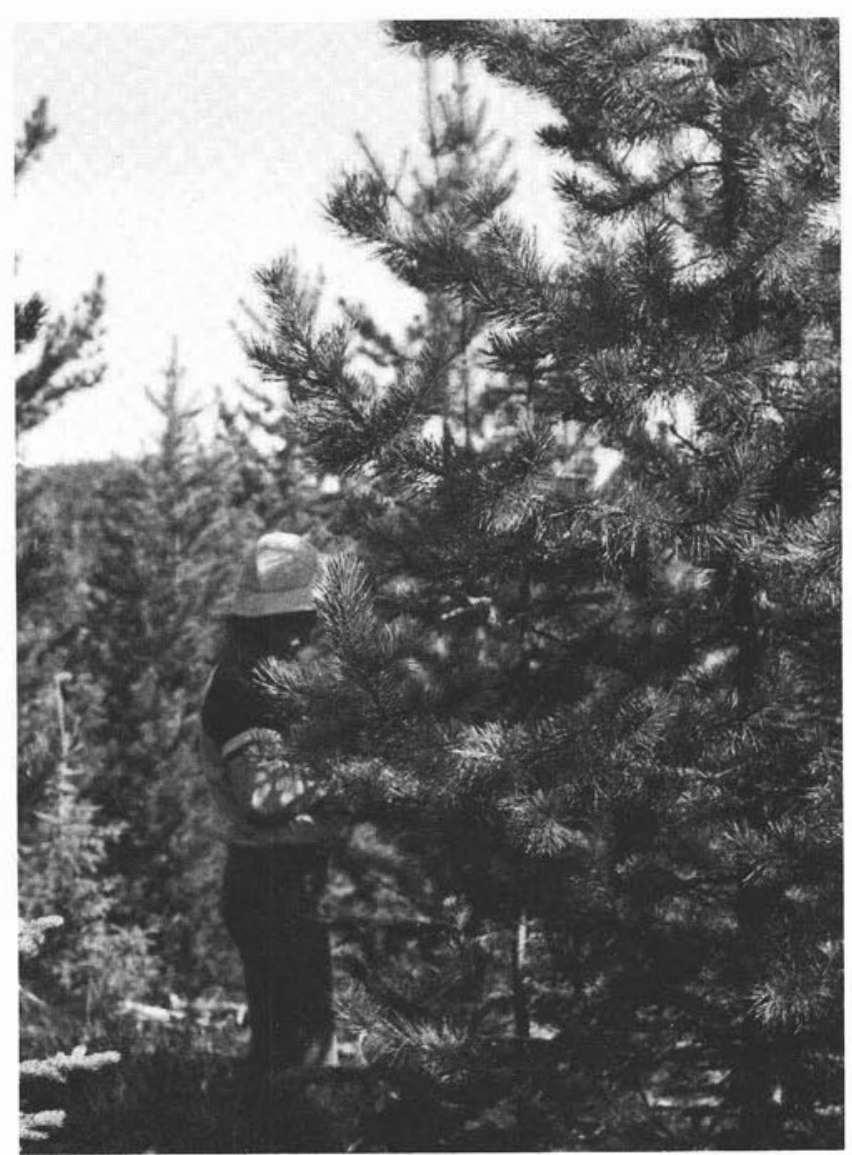

Figure 2. A relatively open 20-year-old lodgepole pine stand in the McLeod working circle that received no thinning.

Table 1. Summary statistics of the stands sampled.

\begin{tabular}{|c|c|c|c|c|c|c|c|c|c|}
\hline \multirow{2}{*}{$\begin{array}{l}\text { Stand } \\
\text { treatment }\end{array}$} & \multicolumn{3}{|c|}{ Number of trees/ha } & \multicolumn{3}{|c|}{ Mean dbh/plot (cm) } & \multicolumn{3}{|c|}{ Mean dominant ht/plot (m) } \\
\hline & Avg. & Min. & Max. & Avg. & Min. & Max. & Avg. & Min. & Max. \\
\hline Unthinned & 8500 & 1000 & 30500 & 4.1 & 1.8 & 7.5 & 4.7 & 2.7 & 7.7 \\
\hline Thinned & 2620 & 1333 & 9333 & 6.2 & 2.7 & 11.7 & 5.0 & 2.4 & 8.7 \\
\hline
\end{tabular}


These damaging agents and damage classes were selected on the basis of prior field observations, from a current summary of insect and disease pests and allied problems affecting lodgepole pine in Alberta (Ives 1983), from personal communications with W.G.H. Ives (CFS, Edmonton), and from discussions with the forestry staff of St. Regis (Alberta) Ltd. at Hinton. The damaging agents selected are among the most important ones in young lodgepole pine stands, and it was reasonable to expect some differences in their occurrence between thinned and unthinned lodgepole pine. In addition to the above classes, damage from atropellis canker (Atropellis piniphila (Weir) Loman \& Cash), Cronartium spp., and Armillaria mellea (Vahl. ex Fr.) Kummer was included, but very little was observed and it was omitted from the analysis. Armillaria generally kills the host, and dead trees were excluded from this survey.

The hypothesis of no difference in categories of damage between thinned and unthinned stands was tested using Chisquare $\left(\chi^{2}\right)$ procedures. The general formula for Chi-square is

$$
\chi^{2}=\sum_{i=1}^{k} \frac{\left(0_{i}-E_{i}\right)^{2}}{E_{i}}
$$

where $k=$ number of groups

$0=$ observed count

$E=$ expected count

The expected counts (E) for each damage condition class were calculated from ratios of tree totals in the unthinned and the thinned categories, based on the premise that the same ratios would apply to counts expected in each damage class in the absence of treatment (thinning) effect. Table 2 illustrates the procedure.

Table 2. Procedure for calculating expected counts by damage class.

\begin{tabular}{cccc}
\hline $\begin{array}{l}\text { Damage } \\
\text { class }\end{array}$ & Unthinned & Treatment & $\begin{array}{c}\text { Total } \\
\text { Thinned }\end{array}$ \\
\hline 0 & $\left.\mathrm{OA}_{\mathbf{1}}+\mathbf{O B}_{\mathbf{1}}\right)$ \\
1 & $\mathrm{OA}_{1}$ & $\mathrm{OB}_{0}$ & $\mathrm{C}_{0}$ \\
2 & $\mathrm{OA}_{2}$ & $\mathrm{OB}_{1}$ & $\mathrm{C}_{1}$ \\
$\vdots$ & $\vdots$ & $\mathrm{OB}_{2}$ & $\mathrm{C}_{2}$ \\
8 & $\mathrm{OA}_{8}$ & $\mathrm{OB}_{8}$ & $\vdots$ \\
\hline Tree totals & $\mathrm{A}$ & $\mathrm{B}$ & $\mathrm{C}+\mathrm{B}$ \\
\hline
\end{tabular}

$\mathrm{OA}_{\mathrm{i}}, \mathrm{OB}_{\mathrm{i}}=$ observed counts by damage class

$E A_{i}, E B_{i}=$ expected counts by damage class

$A, B=$ number of trees

and where:

$E A_{i}=\left(\frac{C i}{A+B}\right) A$

$E B_{i}=\left(\frac{C i}{A+B}\right) B$

All data were pooled for the analysis, and no tests were done on plot or stand bases. Then the data were separated into groups or classes (subsets) by appropriate criteria, e.g., working circles and number of years since thinning, to detect trends and differences in pest damage incidence. A comparison was also made with an independent data set from the same area provided by W.G.H. Ives.

\section{Results and Discussion}

The analyses (Table 3 ) indicated that there were highly significant differences in damage incidence for three damage classes in the unthinned and in thinned stands. Generally,
Table 3. Chi-square by damage class for all plots (unthinned 2065 trees; thinned 899 trees).

\begin{tabular}{lrrrrrr}
\hline \multirow{2}{*}{$\begin{array}{l}\text { Damage } \\
\text { class }\end{array}$} & \multicolumn{2}{c}{ Unthinned } & & \multicolumn{2}{c}{ Thinned } & \\
\cline { 2 - 3 } \cline { 5 - 6 } & Obs. & \multicolumn{1}{c}{ Exp. } & & Obs. & \multicolumn{1}{c}{ Exp. } & $\chi^{\mathbf{2}}$ \\
\hline 0 & 1247 & 1127.25 & & 371 & 490.75 & $41.94^{\star \star}$ \\
1 & 44 & 45.98 & & 22 & 20.02 & .29 \\
2 & 64 & 62.70 & & 26 & 27.30 & .09 \\
3 & 138 & 126.80 & & 44 & 55.20 & 3.26 \\
4 & 368 & 445.88 & & 272 & 194.12 & $44.85^{\star \star}$ \\
5 & 35 & 48.77 & & 35 & 21.23 & $12.82^{\star *}$ \\
6 & 43 & 38.32 & & 12 & 16.68 & 1.88 \\
7 & 333 & 391.54 & & 229 & 170.46 & $28.85^{\star \star}$ \\
8 & 18 & 22.29 & 14 & 9.71 & 2.73 \\
\hline
\end{tabular}

".Significant at 0.01 level; each $\chi^{2}$ has 1 Degree of Freedom

thinned stands had significantly higher incidences of gall rust, leader damage, and needle cast infection, in that order (Fig. 3). The tests also showed a significant reduction in undamaged (Class 0 ) trees after thinning.

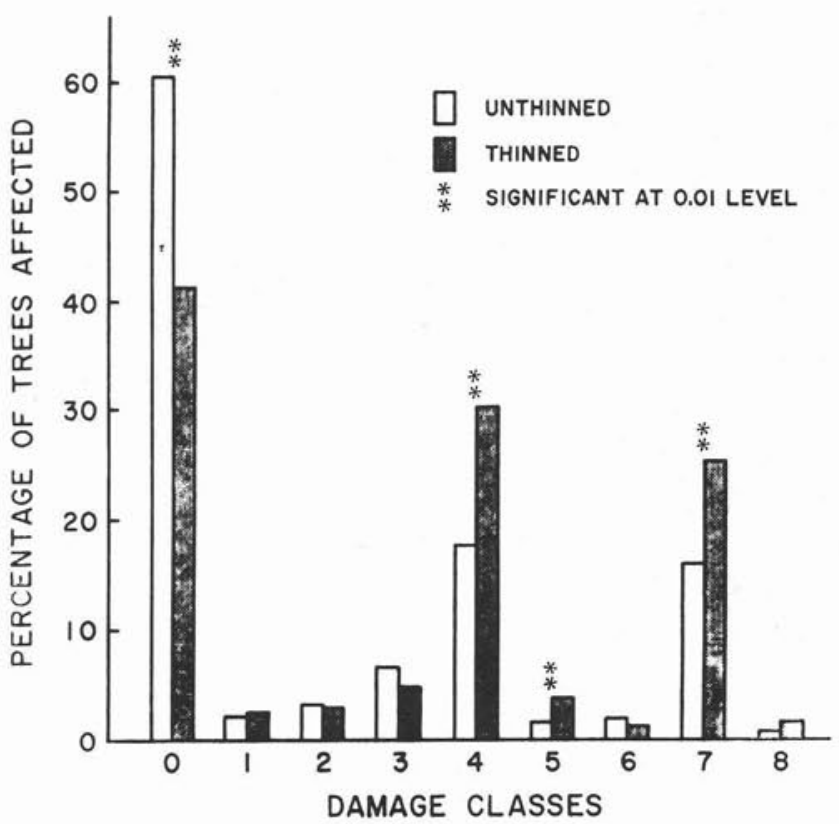

Figure 3. Percentage of lodgepole pine trees affected by damage classes in thinned and unthinned stands for the entire data set.

In practical importance, gall rust (Class 4 ) was the most frequent damaging agent, occurring on about $18 \%$ of the lodgepole pine trees in unthinned stands and on over $30 \%$ of trees in the thinned stands, i.e., more than two-thirds higher in thinned than in unthinned stands. This could be explained by lower densities enhancing the spread of spores by wind from infected trees, and possibly resulting in conditions yet unrecognized, such as more vigorous growth of potential host trees, which may be particularly favorable for fungi establishment.

Similar results have been reported for the Prince George area of British Columbia (Sterner and Davidson 1981), where in mechanically strip-thinned 18-year-old stands that were also hand-spaced in the leave strips, trees in four of the 16 stands examined averaged gall rust infection levels of $30 \%$. In Alberta, Hiratsuka et al. (1981) recognized gall rust as one of the most important disease problems of young, managed hard-pine forests. 
Leader damage (Class 7) was the second most frequent type of damage, again with significantly higher incidence of damage in the thinned than in the unthinned conditions. This damage was caused by the lodgepole terminal weevil and the pitch twig moth, and averaged $16 \%$ for the unthinned and just over $25 \%$ for the thinned stands. These two insects usually damage the tallest, most vigorous trees, whose tops are above the average canopy level. Apparently relatively open stand conditions, as after thinning, may facilitate the movement and spread of these insects, while warmer conditions in the stand, particularly in the forest floor, may be advantageous to their breeding and survival (pers. comm.) $)^{2}$. Some as yet unrecognized tree characteristics induced or enhanced by thinning may also be particularly attractive to these insects. Although the results here show that the relative incidence of damage, expressed as a proportion of trees affected, is substantially greater in thinned stands, some of this difference may be directly related to thinning that removed the smaller trees. Detailed analysis to illuminate this aspect of the problem is in progress and will be published when available.

Needle cast infection (Damage Class 5) incidence was found to be twice as high in thinned than in unthinned stands, but the level of damage was too low ( $5 \%$ or less trees affected) to be important.

${ }^{2 H}$.F. Cerezke, CFS, Edmonton

\section{Influence of Growing Conditions}

To determine whether these results varied with growing conditions, the data were divided into groups of (1) low (McLeod 2 and Berland), (2) medium (McLeod 6 and 9) and (3) high productivity (Marlboro and Embarass) for lodgepole pine

Results for Group 1 (Fig. 4) are very similar to results for the entire data set, probably because this group constitutes nearly $60 \%$ of the data. For Group 3 (Marlboro and Embarass), moderate to heavy stem chewing (Damage Class 3 ) by snowshoe hares (Lepus americanus (Erxleben)) and red squirrels (Tamiasciurus hudsonicus (Erxleben)) was more than twice as frequent in unthinned stands as in thinned stands (17\% vs. $7 \%$ ). Although no special effort was made to identify and describe the actual cause of this damage, in the Marlboro and Embarass working circles at least, most of it was probably caused by hares.

The observed incidence of hare damage agrees with the results published by Sullivan and Sullivan (1982), who found that the proportion of crop trees damaged by hares was greater in stands of high density in the Prince George area. Their results, however, showed incidence of damage by small mammals, including squirrels, to be about twice as high as has been found in this study.

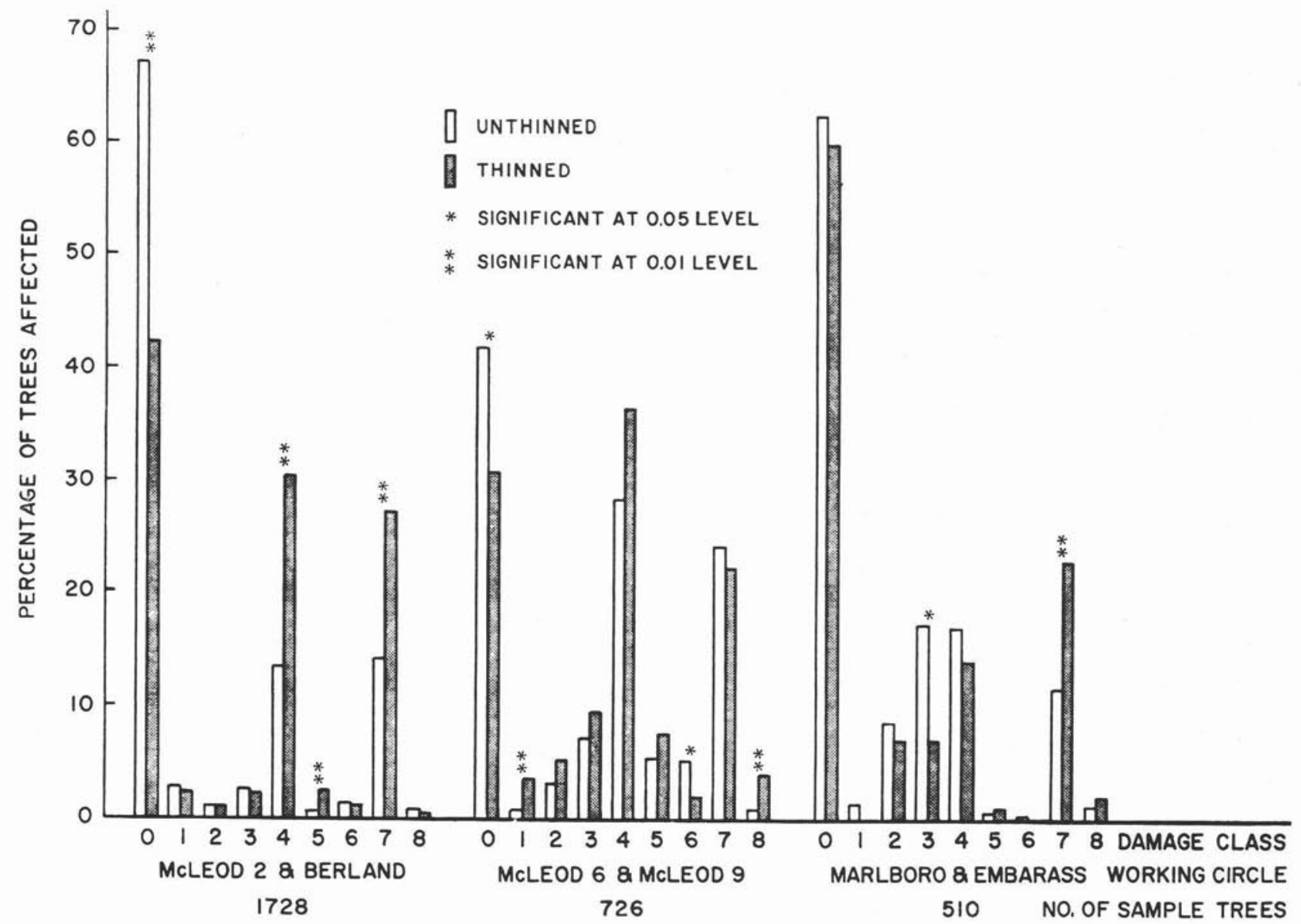

Figure 4. Percentage of lodgepole pine trees affected by damage classes in thinned and unthinned stands by working circle group. 
Also in the Marlboro and Embarass (high productivity) working circles, leader damage from the two insect species was about twice as high in the thinned as in the unthinned stands (23\% vs. $11.5 \%)$.

McLeod 6 and 9 (Group 2) plots showed significant differences in damage incidence between thinned and unthinned stands for browsing damage (Class 1), chlorotic condition (Class 6), and for all other damage not included under Classes 1-7 (Fig. 4). However, the overall damage incidence was too low (generally under $5 \%$ ) to have practical importance.

Variation in the results due to geographic location and related differences in habitats and growing conditions can be expected. Small mammals, particularly hares, may favor warm locations such as southern or western slopes and lower elevations, and their populations and the amount of damage they cause tend to reflect this. For example, Marlboro and Embarass (Group 3 ) represents the lowest elevation and warmest areas in the sample, with more hardwoods and a richer and more abundant shrub and herb layer that offers both food and shelter. These areas have a relatively high incidence of browsing damage from small mammals. Rusts and other fungus infections tend to thrive in sheltered locations with high levels of relative humidity. On the other hand, insects such as pine terminal weevil may favor specific leader growth characteristics, which are a function of site quality. A good example of this is also the Marlboro - Embarass area, where the most favorable growing conditions and the best (also possibly the most succulent) leader growth occurred.

\section{Influence of Time of Thinning}

To explore whether damage incidence was related to time since thinning, the data were separated into two groups by year of thinning: 1) thinned in 1972, 1977, 1978, and 2) thinned in 1979, 1980, 1981. These were the years when thinning was done by the company, although in 1972 and 1981 thinnings the sample consisted of only one pair of thinned and unthinned blocks.

This analysis also showed the incidence of gall rust damage (Class 4 ) and leader damage (Class 7 ) to be the two highest in both groups, and that damage incidence was significantly higher (at 0.01 level probability) in thinned than in unthinned stands (details available on request from the writer). Overall, the level of damage and the difference between thinned and unthinned stands was similar to that shown in Fig. 3. The $1972-78$ group had a somewhat higher (about $25 \%$ ) incidence of gall rust infection than the 1979-81 group for both treatment conditions, while leader damage was generally higher in the 1979-81 group. The latter, somewhat unexpected, result may be due to the unusually high infestation levels by Petrova spp. in the Berland working circle, where the bulk of the 1979-81 data originated. Generally, the scope of the present study and the data do not warrant any generalizations about the effect of time elapsed since thinning on damage incidence.

\section{Independent Verification of Study Results}

A verification of the study results was possible from an independent data $\operatorname{set}^{3}$ that represented essentially the same range of conditions and in the same area, with field procedures similar to those in the present study. For this analysis, a randomly chosen subset (4479 trees from thinned and 2488 from unthinned stands) of the entire data set was obtained so that it included about equal numbers of stands from the two treatments.

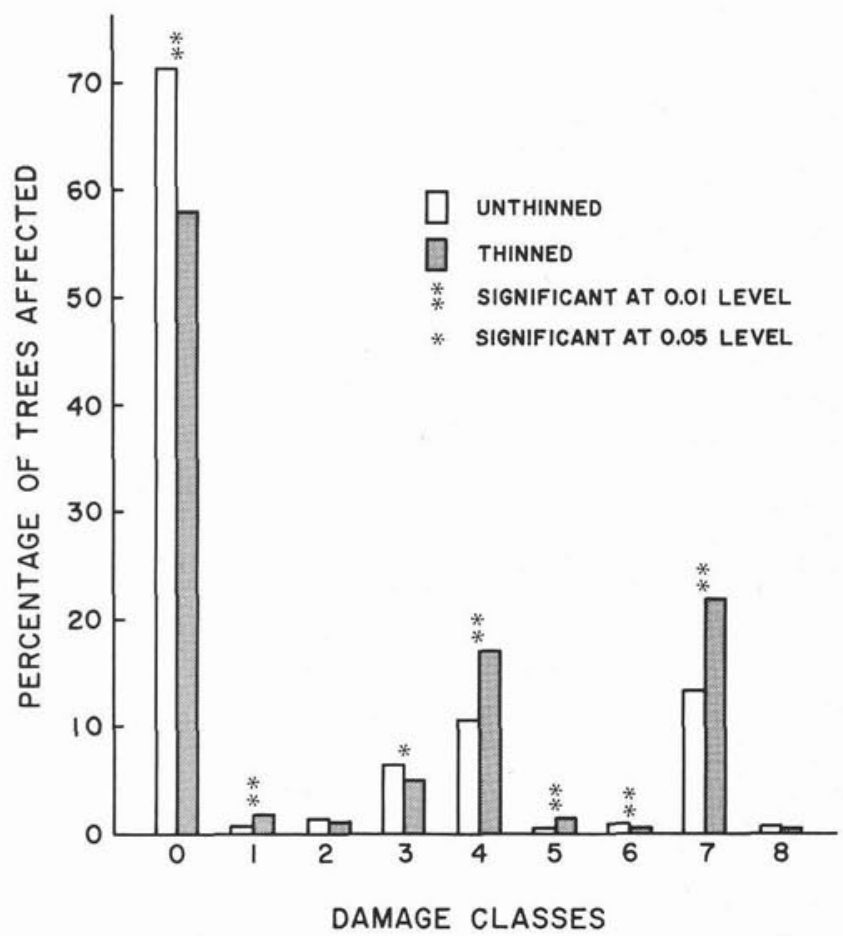

Figure 5. Percentage of lodgepole pine trees affected by damage classes in thinned and unthinned stands for Ives' data.

The analyses of Ives' data (Fig. 5) confirmed the results and trends discussed earlier (Table 3, Fig. 3). Again, gall rust and leader damage incidence were the most common, with thinned stands sustaining nearly two-thirds more damage from each of these causes (i.e., damage increasing from $10.6 \%$ to $17.1 \%$ and from $13.35 \%$ to $22 \%$ of trees, respectively, the differences being significant at the 0.01 level) than unthinned stands. Although damage incidence levels were somewhat lower for this independent data set, the relative differences in damage (between thinned and unthinned stands) for the two damage classes were similar to the study results.

For this data set, the incidence of heavy stem chewing (Damage Class 3), attributed mainly to snowshoe hares, was significantly higher (at 0.05 level probability) in the thinned than in the unthinned stands. The pest incidence in percentage of trees affected (about 5\%), however, was nearly identi$\mathrm{cal}$ to the overall incidence of damage found in the present study (Fig. 3).

Although browsed top and branches (Fig. 5, Damage Class 1) and needle cast infection (Damage Class 5) were twice as frequent in thinned as in unthinned stands (differences significant at the 0.01 level), the percentage of trees affected was too low (under $2 \%$ ) for such damage to have much practical importance. Browsing of the upper part of the stem and branches was generally caused by squirrels, which seem to prefer more open stand conditions. Sullivan and Sullivan (1982) also noted increased damage from squirrels with lower stand density, as found after thinning.

${ }_{3}^{3}$ Made available by W.G.H. Ives, and being collected to evaluate mortality in young lodgepole pine stands. File reports and data summaries provided on request from the NoFRC, Edmonton, T6H 355 


\section{Importance of Damage}

This study was initiated primarily because of the high incidence of small mammal damage that was observed in localized areas. These results show that the overall damage incidence from small mammals to potential crop trees of lodgepole pine in the foothills of west-central Alberta was relatively low, generally under $10 \%$. Thinning may reduce damage by hares and increase squirrel damage; however, actual damage levels associated with small mammals seem to be too low to be important and may not require special consideration in planning thinnings in this area. Snowshoe hare populations, well-known for their fluctuation, were at their 10-year peak in the area in 1981 and 1982. Therefore, the study was well-timed to monitor damage caused by these mammals.

On the other hand, the overall incidence of gall rust and leader damage caused by terminal weevil and pitch twig moth were at fairly high levels in unthinned stands (Fig. 3,18\% and $16 \%$, respectively), and in thinned stands the percentage of trees affected was yet another one-third higher. Although these agents generally do not cause mortality and their incidence and impact are expected to lessen with increasing age, they do tend to reduce tree growth. Top damage also causes multiple leaders, reduces tree height, and results in lower merchantable volume production.

Overall, as much as $60 \%$ of the potential crop trees were affected by one or more damaging agents in thinned stands. Although this in itself is no cause for alarm, it does suggest that it is prudent to leave a good reserve of potential crop trees when spacing young lodgepole pine. This is indeed the current practice of St. Regis (Alberta) Ltd., where thinning aims at leaving about 2500 of the largest well-spaced trees per ha: roughly twice the number of trees required for optimum sawtimber yield at 70 years. The added benefit of such practice is the chance for a commercial thinning to remove these surplus (and possibly damaged) trees for pulpwood 10-20 years before final harvest and thus accelerate the growth of final crop trees and increase their value for sawlogs.

The purpose of this study was to quantify incidence of pest damage in thinned and unthinned young lodgepole pine and evaluate their potential impact on growth and yield. To quantify the effects of pest incidences, i.e., their actual impact on tree growth, mortality and stand yield, requires detailed, long-term studies.

\section{Summary}

The following conclusions were reached in this study:
1. The incidence of damage owing to gall rust and leader damage by terminal weevil and pitch twig moth was about two-thirds greater in the thinned than in the unthinned stands, increasing for gall rust from 18 to $30 \%$ and for leader damage from 16 to $25 \%$. Damage by small mammals was low.

2. To compensate for the long-term impact that this damage may have on growth, it is prudent to leave a surplus of potential crop trees when spacing young lodgepole pine stands. This surplus may be as large as the expected number of final crop trees, i.e., 1000-1200 trees per ha. Such practice would also allow a commercial thinning later.

3. The pest incidence discussed in this study is quite variable over time and space. The present results apply primarily to lodgepole pine cover types in west-central Alberta, under current thinning practice and environmental conditions prevailing in the previous decade. Wider application of these findings requires further verification in other areas of the east slopes and under different thinning and environmental conditions. Pest incidence in young lodgepole pine stands may also differ considerably from those reported from other forest regions.

\section{Acknowledgements}

S. Murray and S. Lux did the field sampling, and S. Lux and V. Kolabinski did most of the computations and drafting. L. Safranyik, PFRC, CFS, Victoria, B.C. offered helpful suggestions about statistical analysis. Credit is due to the forestry staff of St. Regis (Alberta) Ltd. for their help in selecting suitable sampling areas.

\section{References}

Hiratsuka, Y., H.F. Cerezke, J. Petty, and G.N. Still. 1981. Forest insect and disease conditions in Alberta, Saskatchewan, Manitoba and the Northwest Territories in 1980 and predictions for 1981. Environ. Can., Can. For. Serv., North. For. Res. Cent., Edmonton, Alberta. Inf. Rep. NOR-X-231.

Ives, W.G.H. 1983. Insect and disease pests and allied problems affecting lodgepole pine in Alberta. In: Lodgepole pine: regeneration and management. Proc. Fourth Internat. Workshop. USDA For. Serv., Gen. Tech. Rep. PNW-157. p. 32-36.

Johnstone, W.D. 1981. Effect of spacing 7-year-old lodgepole pine in west-central Alberta. Environ. Can., Can. For. Serv., North. For. Res. Cent., Edmonton, Alberta. Inf. Rep. NOR-X-236.

Johnstone, W.D. 1983. Natural lodgepole pine in west-central Alberta. Part II: Juvenile spacing. In: Lodgepole pine: regeneration and management. Proc Fourth Internat. Workshop. USDA For. Serv., Gen. Tech. Rep. PNW-157. p. 8-14.

Rowe, J.S. 1972. Forest regions of Canada. Environ. Can., Can. For. Serv. Publ. 1300 ,

Sterner, T.E. and A.G. Davidson. 1981. Forest insect and disease conditions in Canada 1980. Environ. Can., Can. For. Serv. Ottawa, Ont. 43 p.

Sullivan, T.P. and D.S. Sullivan. 1982. Barking damage by snowshoe hares and red squirrels in lodgepole pine stands in central British Columbia. Can. J. For. Res. 12: 443-448. 